Review

\title{
Current Evidence for Stereotactic Body Radiotherapy in Lung Metastases
}

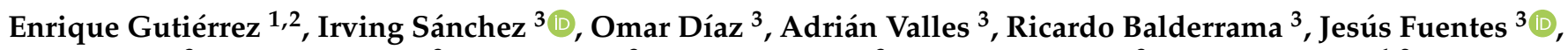 \\ Brenda Lara ${ }^{3}$, Cipatli Olimón ${ }^{3}$, Víctor Ruiz ${ }^{3}$, José Rodríguez ${ }^{3}$, Luis H. Bayardo ${ }^{3}$, Matthew Chan ${ }^{1,2}$, \\ Conrad J. Villafuerte ${ }^{1,2}$, Jerusha Padayachee ${ }^{1,2}$ and Alexander Sun ${ }^{1,2, *}$
}

1 Princess Margaret Cancer Centre, Radiation Medicine Program, University Health Network, Toronto, ON M5G2M9, Canada; Enrique.Gutierrez@rmp.uhn.ca (E.G.); matthew.chan@bccancer.bc.ca (M.C.); Conrad.Villafuerte@rmp.uhn.ca (C.J.V.); Jerusha.Padayachee@rmp.uhn.ca (J.P.)

2 Department of Radiation Oncology, University of Toronto, Toronto, ON M5G2M9, Canada

3 Western National Medical Center, Department of Radiation Oncology, Mexican Institute of Social Security (IMSS), Belisario Domínguez 1000, Guadalajara 44340, Jalisco, Mexico; irvingsanchez.md@gmail.com (I.S.); omardiazcazares@gmail.com (O.D.); advaqui@hotmail.com (A.V.); ricardoivan.balderrama@gmail.com (R.B.); drfuentes@protonmail.com (J.F.); brendalara912@hotmail.com (B.L.); drolimon@hotmail.com (C.O.); victormjrp5@gmail.com (V.R.); Jose_2906@hotmail.com (J.R.); luis.bayardo@imss.gob.mx (L.H.B.)

* Correspondence: Alex.Sun@rmp.uhn.ca; Tel.: +1-41-6946-2853

check for updates

Citation: Gutiérrez, E.; Sánchez, I.; Díaz, O.; Valles, A.; Balderrama, R.; Fuentes, J.; Lara, B.; Olimón, C.; Ruiz, V.; Rodríguez, J.; et al. Current Evidence for Stereotactic Body Radiotherapy in Lung Metastases. Curr. Oncol. 2021, 28, 2560-2578. https://doi.org/10.3390/ curroncol28040233

Received: 5 May 2021

Accepted: 6 July 2021

Published: 15 July 2021

Publisher's Note: MDPI stays neutral with regard to jurisdictional claims in published maps and institutional affiliations.

Copyright: (c) 2021 by the authors. Licensee MDPI, Basel, Switzerland. This article is an open access article distributed under the terms and conditions of the Creative Commons Attribution (CC BY) license (https:/ / creativecommons.org/licenses/by/ $4.0 /)$.

\begin{abstract}
Lung metastases are the second most common malignant neoplasms of the lung. It is estimated that $20-54 \%$ of cancer patients have lung metastases at some point during their disease course, and at least $50 \%$ of cancer-related deaths occur at this stage. Lung metastases are widely accepted to be oligometastatic when five lesions or less occur separately in up to three organs. Stereotactic body radiation therapy (SBRT) is a noninvasive, safe, and effective treatment for metastatic lung disease in carefully selected patients. There is no current consensus on the ideal dose and fractionation for SBRT in lung metastases, and it is the subject of study in ongoing clinical trials, which examines different locations in the lung (central and peripheral). This review discusses current indications, fractionations, challenges, and technical requirements for lung SBRT.
\end{abstract}

Keywords: lung SBRT; oligometastatic disease; lung cancer; lung metastases

\section{Introduction}

Historically the standard treatment for metastatic disease has been with systemic therapy alone. However, more recent evidence from the retrospective and prospective series indicates improved long-term results when patients are managed with the addition of aggressive local treatments [1-9]

Lung metastases develop in $20-54 \%$ of cancer patients at some point in their disease [10]. At least 50\% of cancer-related deaths occur at this stage. Budczies et al. conducted a cohort study in 1008 postmortem patients, and the lung was the third most frequent site of metastases of 16 types of solid cancer [11]. Some authors consider it to be the second most frequent site $[10,11]$ of metastatic target for neoplastic cells since it has a microenvironment that is rich in vascular supply, as well as containing small capillaries with a very short distance to the intravascular space [12]. In 1889, Paget proposed that metastatic disease does not progress randomly but in a process that has recently been termed the metastatic cascade [12]. This process includes the steps of angiogenesis, intravasation, survival in circulation, extravasation, establishment, and growth $[13,14]$.

Cancer cells migrate towards higher-oxygen areas, which can be achieved through the epithelial-mesenchymal transition, orientation, interaction within the stroma, and evasion of the immune system [13]. 
As the tumor grows, physical barriers, such as the basement membrane and interstitial connective tissue, must degrade for tumor invasion to occur. Proteolytic enzymes (e.g., collagenase, trypsin, plasmin, and cathepsin B) and matrix metalloprotease expressed in tumor cells facilitate tumor spread by denaturalizing the extracellular matrix, migration, and chemotaxis, also called intravasation [10]. Hematogenic spread occurs mainly through the venous drainage system and the pulmonary arteries (but is less common through the bronchial arteries) [13]. Lymphatic spread and tracheobronchial spread are unusual, accounting for $2-5 \%$ of pulmonary metastases, and direct extension is the least common pathway of all [10].

Finally, the proliferation of metastatic foci is succeeded by the production of proangiogenic factors such as vascular endothelial growth factor, fibroblast growth factor, and interleukin-8 (IL-8) [14].

\section{Definition of Oligometastatic Disease}

The term oligometastasis first appeared in 1995 and defines a state between localized and widely disseminated disease $[15,16]$. This concept was consolidated by integrating the elements of the size and number of lesions that occur synchronously (at diagnosis of the primary tumor or up to 3 months later) or after treatment $[17,18]$. An oligometastatic status indicates the candidacy for radical treatment for both primary and metastatic tumors $[7,19,20]$.

Another scenario in which the benefit of treatment is being analyzed is oligoprogression, a state where only a limited number of metastases progress, while the rest remain stable or respond to systemic treatment $[19,21]$. The treatment options are to change systemic therapy, continue with a given same scheme (in minimal progression) or delay changing the systemic therapy by adding local treatment, such as stereotactic body radiation therapy (SBRT) $[19,21]$.

\section{Number of Metastases}

Oligometastatic disease (OMD) has been defined as having up to five lesions occurring separately and distributed in up to three organs [22]. There is no standardized definition, but the SABR-COMET protocol adopts this definition for its inclusion criteria, indicating also that the maximum number of metastases per organ must be equal to or less than three lesions [23]. Multiple retrospective studies have also used a cut-off point of five lesions [7,24-27], including patients with extrathoracic metastasis, who were candidates for the treatment with radical intent [24,25]. However, other studies, including ongoing studies have included up to 10 lesions [28]. Schanne et al. analyzed patients with Nonsmall cell lung cancer (NSCLC) and oligometastatic disease across 54 studies where $90.5 \%$ of patients had a single metastatic lesion. Most studies have described in different ways the term OMD as it has been defined with significant variation regarding the size and the number of lesions [22]. Therefore, the term OMD continues to be defined. Although the number of metastatic lesions included has varied among different protocols, most trials have identified three or fewer metastases. Consequently, this number could serve as a cut-off point that guides radical management in OMD in the future $[5,23,27,29]$.

Yamamoto et al. concluded that patients with more than five lesions could be treated, as long as dose constraints are achieved. However, in that study, most patients $(74 \%)$ had a unique lesion [27]. Another critical factor is lesion size. Rusthoven et al. used a cut-off point of $7 \mathrm{~cm}$ per lesion [30] and Salame et al. included patients with lesions up to $10 \mathrm{~cm}$ or $500 \mathrm{~cm}^{3}$ [26].

\section{Diagnosis and Imaging of Lung Metastases Imaging Studies}

A chest X-ray is a low-sensitivity tool that cannot detect lesions of less than $1 \mathrm{~cm}$ [31]. In patients with extrathoracic cancer, detection of a new nodule on an X-ray has a $25 \%$ probability of indicating a metastatic lesion [32]. 
Chest computed tomography (CT) with slices of $1-1.25 \mathrm{~mm}$ is the preferred approach for assessing lungs to evaluate and determine the size of the lesion [27]. The characteristics of a metastatic lesion are widely variable. A new nodule $>10 \mathrm{~mm}$ has a $15 \%$ chance of malignancy, as shown in Figure 1. However, regardless of its size, an extrathoracic primary with a new lung lesion is highly suggestive of metastases. Malignant lesions commonly occur with spiculated and irregular margins. However, metastases should not be ruled out if the lesions are rounded and smooth [33].

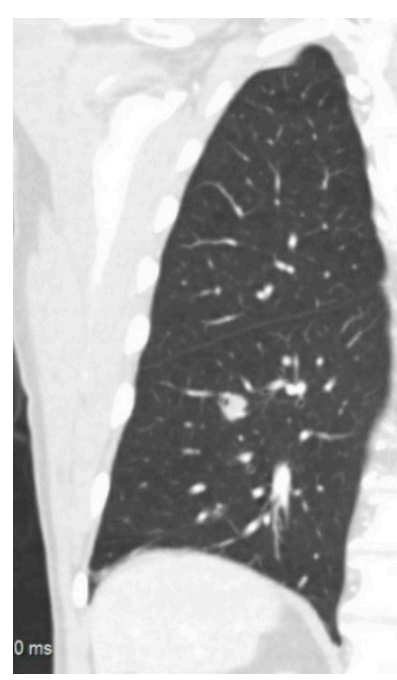

(a)

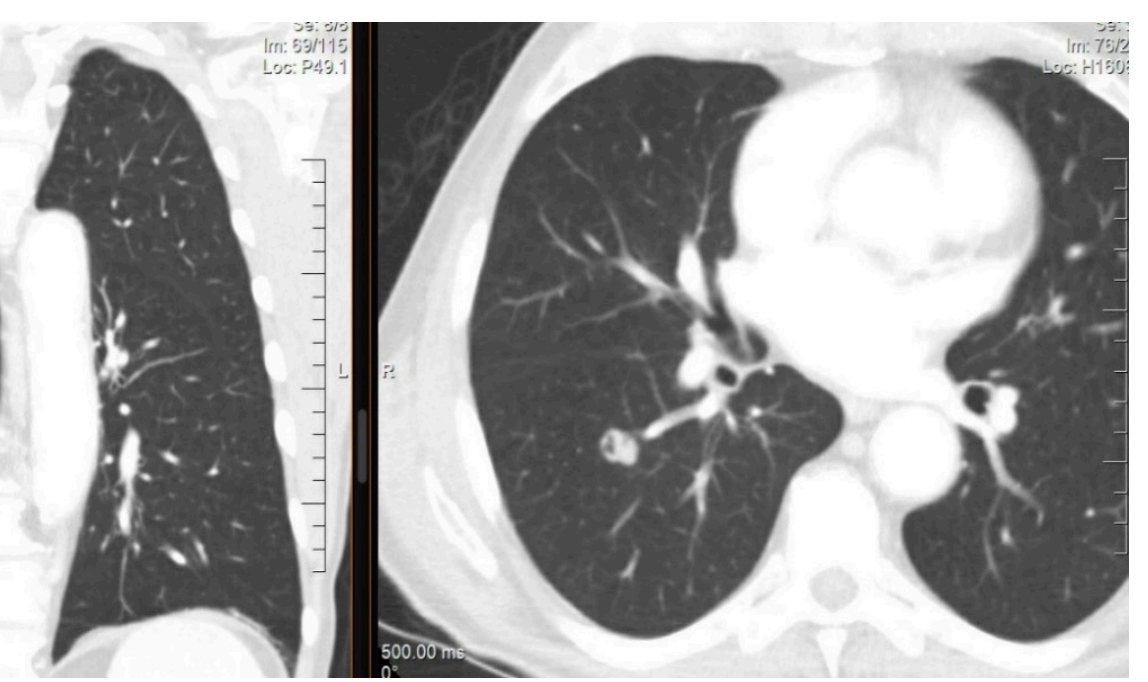

(b)

Figure 1. CT of the chest (a) coronal view and (b) axial view showing a nodule in the right lower lobe measuring $1.5 \mathrm{~cm}$, lobulated and cavitated. The lesion was biopsied and revealed an adenocarcinoma with cytomorphology and an immunoprofile that was consistent with a colorectal primary.

Fluorodeoxyglucose-positron emission tomography (FDG-PET) is a highly sensitive approach for the detection of malignant lesions with solid characteristics and larger than $8 \mathrm{~mm}$, showing a sensitivity of $89 \%$ (95\% CI, 86-91\%) and a specificity of $75 \%$ (95\% CI, $71-79 \%$ ) [34]. The capacity of FDG-PET to detect pulmonary metastases and its relation to the treatment results of lung SBRT can be characterized by SUVmax, SUVmedian, and metabolic tumor volume (MTV). In a study by Mazzola et al., prior to the SBRT treatment, the mean SUVmax was 6.5 (range 4-17), the mean SUVmedian was 3.7 (range 2.5-6.5), and the mean MTV was 2.3 (range $0.2-31$ ) $\mathrm{cm}^{3}$. A SUVmax $<5$ and a SUVmedian $<3.5$ were associated with a full response at 6 months [35]. Among patients who underwent metastasectomy, those with SUVmax $>4.5$ (51.6\% vs. $74.0 \%)$ had a decreased 5-year overall survival [36]. According to Mayo Clinic and Department of Veterans Affairs (VA) models, another relevant tool is the pre-test probability of malignancy based on clinical characteristics and radiographic findings (age, smoking history, history of extrathoracic cancer, the diameter of the nodule in $\mathrm{mm}$, and localization within the upper lobe) [37]. If PETscan results are negative and the pre-test probability is equal to or greater than $65 \%$, a needle-biopsy or video-assisted thoracic surgery should be considered [38]. In patients with an indeterminate solitary pulmonary nodule (SPN) $>8-10 \mathrm{~mm}$ in diameter, a biopsy is recommended in the following situations: (1) Pre-test probability and radiographic findings are discordant, (2) benign diagnosis is suspected, and (3) when a fully informed patient desires proof of a malignant diagnosis before surgery, especially when the risk for surgical complications is high [39].

The possibility of technical artifacts should be taken into account. Catheters, metallic prostheses, and other devices can show more FDG uptake and overestimate affected areas. Another possible artifact is one generated by different respiratory phases when PET is combined with CT, being the most common site of discrepancy the lung-diaphragm limits, potentially confusing the avid areas of FDG of the liver with lung lesions [40]. 
Another alternative under evaluation is the use of liquid biopsies from blood samples, where nucleic acids from tumor cells can be identified [18]. Lebofsky et al. analyzed patients with recurrent/metastatic cancer and failure of standard therapy, a biopsy was compared to circulating tumor DNA determination, and a 97\% match was achieved [41].

\section{Stereotactic Body Radiation Therapy for the Lung}

Stereotactic body radiation therapy (SBRT) is a noninvasive cancer treatment that uses high doses of precise radiation to extracranial target sites [42]. The American Association of Physicists in Medicine (AAPM) defines SBRT as a stereotactic treatment that delivers a high dose of radiation within a short cycle, generally limited to less than or equal to five fractions with a dose of 6 to $34 \mathrm{~Gy}$ per fraction [43,44]. Outside the United States, SBRT has been accepted as a highly conformal technique with regimens including up to 10 fractions with a biologically effective dose (BED) $\geq 100 \mathrm{~Gy}_{10}$ or doses at least biologically equivalent to a radical course of treatment when given over a protracted conventionally (1.8-3 Gy/fraction) fractionated schedule [43,45-47].

However, groups in several countries (AAPM, ASTRO, ACR, CARO-SBRT, and the NRIG) agree on the following points: SBRT is an external beam radiotherapy method that accurately delivers a high dose of radiation in one or a few fractions, to an extracranial target, which results in an increased effective biological dose [45,47].

\section{Radiobiological Principles of SBRT}

The loss of reproductive ability due to the creation of double-stranded breaks in DNA is the primary mechanism by which conventional irradiation kills a cell: Any cell that is unable to reproduce indefinitely is considered to be dead by definition, although it may remain metabolically active for some time [48,49].

Five critical factors determine the effects of radiotherapy on tumors:

1. Repair of sublethal cell damage;

2. Cell repopulation followed by radiation;

3. Cell redistribution in the cell cycle;

4. Re-oxygenation of surviving cells;

5. Radiosensitivity (intrinsic) [48,49].

If a given dose of radiotherapy is divided into daily fractions according to a conventional scheme, redistribution and re-oxygenation facilitate the increase in cell death by redistributing resistant survivors into more radiosensitive phases over time. However, cell repair and repopulation produce increased numbers of surviving cells due to cell recovery and repopulation between doses [48].

Following radiation, three phases of histopathologic change in the lungs have been described. The early/latent phase occurs within a month after radiation and is characterized by the loss of type I alveolar epithelial cells (AEC), alveolar transudates, interstitial edema, and type II AEC morphologic changes. The acute exudative phase (radiation pneumonitis) occurs between three weeks and up to 6 months after radiation. This phase presents fibrin-rich exudates, interstitial edema, and accumulation of alveolar macrophages. The late or fibrotic phase begins approximately 6 months after radiation and is defined by a constant loss of type I AEC, capillary loss, and progressive collagen deposition [50].

For SBRT, there were initial queries on whether the mechanism of action of the killing of tumor cells is similar to conventional radiotherapy. Several studies have shown that the radiobiology of SBRT is quite different [51-54].

The influence of the five Rs on the treatment outcome is modified with the use of SBRT. Due to the shorter treatment time and decreased number of fractions, tumor repopulation and redistribution effects are diminished [52,55]. The steep dose gradients lessen the impact of normal organ sparing [47,52]. Reoxygenation and radiosensitivity remain as factors. However, acute hypoxia and fast reoxygenation are more commonly observed with SBRT compared to chronic hypoxia and slow reoxygenation [52,56-58]. 
Tumor cell death from SBRT can be a result of the combination of direct tumor cell eradication and indirect tumor cell killing secondary to vascular or endothelial damage $[51,52,54,59,60]$. Vascular damage could indirectly lead to tumor death for two reasons. SBRT can abruptly cut off blood supply and can induce endothelial apoptosis, which can heighten tumor radiosensitivity [54,61,62].

Numerous reports have described that vascular tumor damage as tumor volume decreases after being irradiated with a dose higher than $10 \mathrm{~Gy}$ in a single event. The vascular tumor structures become disorganized and fragmented [51,53]. Endothelial tumor cells die as a result of direct radiation damage, vascular permeability, and plasma extravasation, causing erythrocyte concentration within the narrow capillaries, leading to retardation, blood stasis, and vascular collapse [53].

Immune reactions and death of cancer stem cells are also thought to contribute to SBRT radiobiology [52-54]. It has been suggested that SBRT also provokes an immune reaction by increasing T-cell, leading to reduction of the primary tumor cells or distant metastases in a $\mathrm{CD}_{8+} \mathrm{T}$-cell dependent fashion [51].

Cancer stem cells are described as being perivascular. They are considered to be a possible cause of radioresistance in conventional radiotherapy as they are able to reproliferate even after irradiation. SBRT is thought to be able to eradicate these stem cells, thereby decreasing the chances of recurrence [53,54].

\section{Eligible Patients}

Pulmonary comorbidity is the most common reason for inoperability. Patients who are considered medically inoperable are defined based on poor lung function evaluated by a thoracic surgeon or respirologist and encompassing the following parameters: Predicted forced expiratory volume in $1 \mathrm{~s}$ (FEV1) < 40\%, predicted postoperative FEV1 <30\%, baseline hypoxemia ( $\leq 70 \mathrm{mmHg}$ ) and/or hypercapnia (>50 $\mathrm{mmHg})$, predicted reduced diffusing capacity $<40 \%$ and predicted consumption during exercise $<50 \%[63,64]$. Poor lung function by itself is not a contraindication for SBRT. There is no lower limit of lung function prior to SBRT treatment and may even be offered for patients with extreme pulmonary comorbidities [65].

Inoperability also encompasses serious comorbidities such as severe pulmonary hypertension; diabetes mellitus with end organ damage; cerebral vascular disease; severe chronic heart disease or severe cardiovascular disease $[41,66,67]$ SBRT is recommended as a treatment option for this population if they have an estimated life expectancy greater than 1 year [68].

Additional criteria for eligibility include refusing surgical intervention [41,69], recurrent or metastatic lung lesions [69], Eastern Cooperative Oncology Group score $\leq 3$ [67,68] or controlled primary $[24,69]$. There is no contraindication in terms of age $[68,70]$ (see Table 1).

Table 1. Patient eligibility criteria for SBRT.

\begin{tabular}{cc}
\hline Age & Any \\
\hline ECOG & $0-2$ \\
Medically operable patients & Patients who refuse surgical intervention \\
Number of lesions & Range $1-5$ \\
Tumor diameter & $<50 \mathrm{~mm}$ \\
Location & Peripheral \\
& Central \\
\hline
\end{tabular}


Table 1. Cont.

\begin{tabular}{cc}
\hline Age & Any \\
\hline Pedically inoperable patients & Poor lung function: \\
FEV $1<40 \%$ predicted, & \\
& postoperative FEV $1<30 \%$ predicted, \\
decrease diffusing capacity $<40 \%$ predicted, \\
baseline hypoxemia $(\leq 70 \mathrm{~mm} \mathrm{Hg})$ and $/$ or \\
hypercapnia $(>50$ mmHg $)$, and oxygen \\
consumption during exercise $<50 \%$ predicted. \\
Important comorbidities: Severe pulmonary \\
hypertension; diabetes mellitus with \\
end-organ damage; severe cerebral, \\
cardiovascular or peripheral vascular disease; \\
or severe chronic heart disease
\end{tabular}

ECOG: Eastern. Operative Oncology Group Scale of performance status. FEV1: Forced Expiratory Volume in the first second.

\subsection{Considerations of the Number and Size of Metastases}

In May 2020, Bernard et al. reported the case of a patient with five metastatic lung lesions that were treated synchronously with SBRT, followed by two additional lesions also treated synchronously with SBRT, for a total of seven lesions in the same lung, separated by less than $5 \mathrm{~cm}$. After a 14-month follow-up, the authors found no progression and no significant late side effects [71].

In relation to the size of treatable lesions, a study by the German Society for Radio Oncology (DEGRO) established a consensual limit of lung tumor size for SBRT of 4 to $5 \mathrm{~cm}$, with a more fractionated regimen for larger tumors [72].

In one of the largest series of metastatic lung tumors treated with SBRT, the experience of the RSSearch ${ }^{\circledR}$ Patient Registry, the median number of metastases was 1 (1 to 3), with a mean volume of $10.58 \mathrm{cc}(0.1$ to $654.5 \mathrm{cc})$. The mean overall survival for the entire group was 26 months. The overall survival at 1,3 , and 5 years was $74.1 \%, 33.3 \%$, and $21.8 \%$ of patients, respectively. The mean local control (LC) for the group was 53 months. The LC rate at 1, 3, and 5 years was $80.4 \%, 58.9 \%$, and $46.2 \%$, respectively. A statistically significant difference was identified, with improvement in local control for minor tumors. Local control at 2 years was $72.9 \%, 64.2 \%$, and $45.6 \%$ for tumor volume $<11 \mathrm{cc}, 11-27 \mathrm{cc}$, and $>27 \mathrm{cc}$, respectively ( $p=0.0005$ by the log-rank test; $p=0.0011$ by the Gehan-Breslow-Wilcoxon test). This translated into an improvement in OS, with a 2-year OS of $62.4 \%, 60.9 \%$, and $46.1 \%$ for tumors with volumes of $<11 \mathrm{cc}, 11-27 \mathrm{cc}$, and $>27 \mathrm{cc}$, respectively, and the mean OS for lesions <11 cc, 11-27 cc, and >27 cc was 29, 31, and 21 months, respectively ( $p=0.0023$ by the log-rank test; $p=0.0011$ by the Gehan-Breslow-Wilcoxon test) [70].

The ASTRO 2017 evidence-based guideline for NSCLC established that SBRT is an appropriate option for tumors $>5 \mathrm{~cm}$ in diameter within an acceptable therapeutic range. However, this applies to primary lung tumors, with conditional strength of recommendation and a low quality of evidence [42].

Few results have been produced specifically for the use of SBRT in larger lung tumors [73].

\subsection{Peripheral and Central Lesions: Technical, Fractional, and Dose Prescription Differences}

Traditionally, only patients with tumors at least $2 \mathrm{~cm}$ away from the bronchial tree have been considered for SBRT, following a commonly used three to four fraction regimen [15] (Figure 2). However, at present, patients with central tumors, defined as those where the closest point is within $2 \mathrm{~cm}$ proximal to (but not contacting or abutting) the main bronchial tree or within $2 \mathrm{~cm}$ (contacting or not) of mediastinal structures [74,75], are at higher risk for toxicity when treated with SBRT, compared to patients with peripheral tumors [34], avoiding the use of a three-fraction regimen is recommended in this scenario [42]. Tumors 
with the highest risk for SBRT are those with an ultra-central location, defined as any GTV at $\leq 1 \mathrm{~cm}$ from the proximal bronchial tree that overlaps the trachea or the main bronchus [75] or tumors that contact (abut) the proximal bronchial tree [74,75]. High rates of toxicity and death are associated with treatment in this situation, increasing the interest in identifying an optimal, effective, and safe dose for this group of patients [76].

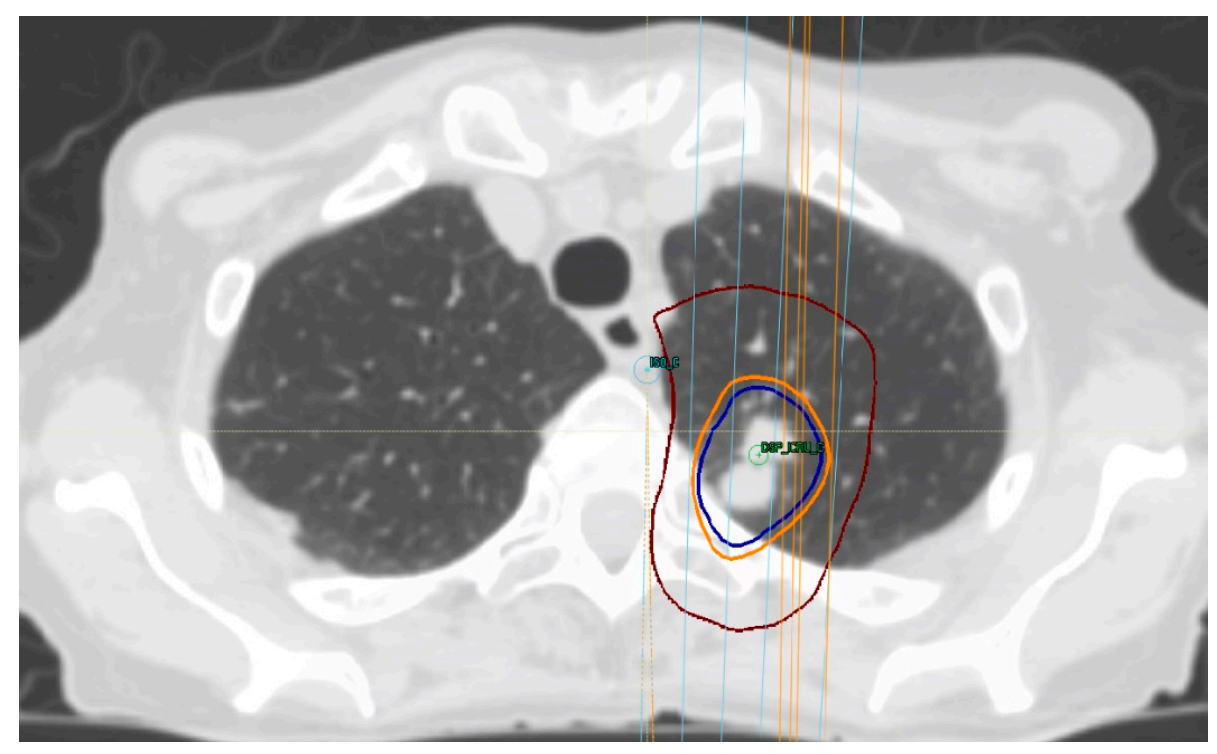

Figure 2. Treatment-planning dose for lung SBRT in a patient with biopsy-proven metastatic breast cancer, prescribing $48 \mathrm{~Gy}$ in four fractions. Isodose lines: Burgundy, $24 \mathrm{~Gy}$; light orange, $44 \mathrm{~Gy}$; and blue, 48 Gy.

To reduce the probability of these complications, Bral et al. proposed a treatment with adapted risk fractions, increasing the number of fractions to the range of five to eight and with doses per fraction of 4-8 Gy, which have shown acceptable toxicity [77].

For central tumors in which SBRT is considered very high risk, hypofractionated radiotherapy using 6-15 fractions can be considered, transposing what is established by the ASTRO guideline for NSCLC in the early stages [42].

Timmerman et al. reported high rates of toxicity associated with central tumors compared to peripheral ones in the definitive treatment setting for patients with NSCLC [76]. Likewise, Lischalk et al. demonstrated a rate of local control of $57.4 \%$ at 2 years, significantly lower than that reported by Timmerman (95\%) [78].

More recent retrospective data that include heterogeneous dose and fractionation schedules seem to indicate that the risk for irradiation in the central regions may not have the significant impact postulated by Timmerman et al. [76,78,79]. Chaudhuri et al. observed that this group of central tumors (including primary NSCLC and lung metastases) exhibited excellent tumor control and a similar toxicity rate to its less central counterpart, suggesting that even ultra-central tumors can be treated with $50 \mathrm{~Gy}$ in four or five fractions if not in contact with the esophagus [80].

The fractionation of $50 \mathrm{~Gy}$ in five fractions was described by Bezjak et al. in the context of early-stage NSCLC, reporting reasonable control rates and acceptable toxicities [81]. In this context, the NRG-BR001 clinical trial was designed, which is currently evaluating prescribed doses for lung metastases of $45 \mathrm{~Gy}$ in three fractions for peripheral lesions and $50 \mathrm{~Gy}$ in five fractions for central lesions. The successful completion of this trial will provide valuable information for the design of new clinical trials and the development of treatment guidelines for oligometastatic disease [82].

There is no consensus at present on the ideal dose and fractionation for SBRT in lung metastases $[78,80]$. A brief summary of published studies regarding differences in dose and fractionation for SBRT for lung metastases according to central or peripheral location is depicted in Table 2. 
Table 2. Brief Summary of published studies of lung SBRT-treated central and central/peripheral lung metastases and differences in the prescribed dose.

\begin{tabular}{|c|c|c|c|c|c|c|}
\hline Author/Year & Location & Technique Description & Prescribed Dose & Local Control & Overall Survival & Grade $>3$ Toxicity \\
\hline $\begin{array}{l}\text { Milano et al. } \\
2009 \text { [79] }\end{array}$ & Central & $\begin{array}{l}\text { Relaxed end-expiratory } \\
\text { breath holding }\end{array}$ & Dmean 50 Gy (30-63 Gy) most in 4-5 Gy per fx & $73 \%$ at $2 \mathrm{yr}$ & $47 \%$ at $2 \mathrm{yr}$ & $5 / 53$ pts w/grade 5 \\
\hline $\begin{array}{l}\text { Unger et al. } \\
2010[83]\end{array}$ & Central & $\begin{array}{l}\text { CyberKnife system with } \\
\text { synchrony fiducial } \\
\text { tracking technology }\end{array}$ & $30-40$ Gy in $5 \mathrm{fx}$ & $63 \%$ at $1 \mathrm{yr}$ & $54 \%$ at $1 \mathrm{yr}$ & $\begin{array}{l}3 / 20 \text { pts } \mathrm{w} / \text { severe } \\
\text { pneumonitis }\end{array}$ \\
\hline $\begin{array}{l}\text { Rowe et al. } \\
2012 \text { [84] }\end{array}$ & Central 100\% & $\begin{array}{l}\text { 4D-CT with ITV and } \\
\text { CBCT guidance system }\end{array}$ & $\begin{array}{c}\text { 75\% BED } 100 \text { Gy } 57 \% 12.5 \text { Gy } \times 4 \text { fx 25\% BED } \\
<100 \text { Gy }\end{array}$ & $75 \%$ at $2 \mathrm{yr}$ & $\longrightarrow$ & $5 / 47$ patients \\
\hline $\begin{array}{l}\text { Nuyttens et al. } \\
2012[85]\end{array}$ & Central & $\begin{array}{l}\text { CyberKnife respiratory } \\
\text { tumor tracking system }\end{array}$ & $45-60 \mathrm{~Gy} / 5-6 \mathrm{Fx}$ & $64 \%$ at $2 \mathrm{yr}$ & $75 \%$ at $2 \mathrm{yr}$ & $\begin{array}{c}\text { No grade } 4-5 \text { toxicity, } \\
17.12 \% \text { grade } 3\end{array}$ \\
\hline \multirow[t]{2}{*}{$\begin{array}{l}\text { Nuyttens et al. } \\
2014[86]\end{array}$} & $\begin{array}{c}\text { Peripheral Size }>3 \mathrm{~cm} \\
\text { Peripheral Size }<3 \mathrm{~cm} \\
\text { Central } \\
\text { Central in contact with }\end{array}$ & $\begin{array}{l}\text { Real-time tumor tracking } \\
\text { + radiopaque markers }\end{array}$ & $\begin{array}{l}60 \mathrm{~Gy} / 3 \mathrm{fx} \\
30 \mathrm{~Gy} / 1 \mathrm{fx} \\
60 \mathrm{~Gy} / 5 \mathrm{fx}\end{array}$ & $\begin{array}{l}90 \% \text { at } 2 \mathrm{yr} \\
74 \% \text { at } 2 \mathrm{yr} \\
100 \% \text { at } 2 \mathrm{yr}\end{array}$ & $58 \%$ at $3 \mathrm{yr}$ & \multirow[t]{2}{*}{ No grade $4-5$ toxicity } \\
\hline & & & $56 \mathrm{~Gy} / 7 \mathrm{fx}$ & $100 \%$ at $2 \mathrm{yr}$ & & \\
\hline $\begin{array}{l}\text { Chaudhuri et al. } \\
2015[80]\end{array}$ & $\begin{array}{l}\text { Central } 50 \% \\
\text { Peripheral } 50 \%\end{array}$ & $\begin{array}{l}\mathrm{IMRT} / 4 \mathrm{D}-\mathrm{CT} / \mathrm{PET} \\
\text { respiratory gating }\end{array}$ & $\begin{array}{l}(78 \%) 50 \mathrm{~Gy} / 4 \mathrm{fx} ;(22 \%) 50.4 \mathrm{~Gy} / 5 \mathrm{fx} \text {. } \\
\text { Proportionally, more centrally located with } 5 \mathrm{fx} \text {. }\end{array}$ & $\longrightarrow$ & $\begin{array}{l}\quad 73.8 \% \text { at } 2 \mathrm{yr} \\
\text { No differences regarding }\end{array}$ & $\begin{array}{l}3 \% \text { at } 3 \mathrm{yr} \\
11.6 \% \text { at } 3 \mathrm{yr}\end{array}$ \\
\hline $\begin{array}{l}\text { Davis et al. } \\
2015 \text { [76] }\end{array}$ & Central & $\begin{array}{l}\text { CyberKnife with } \\
\text { synchrony respiratory } \\
\text { motion tracking system }\end{array}$ & $\begin{array}{c}\text { Dmean } 37.5 \text { Gy (16-60 Gy) in 1-5 fx (media } \\
3 \text { fx), Dmean BED 93.6 Gy }\end{array}$ & $69.8 \%$ at $2 \mathrm{yr}$ & $\begin{array}{l}\text { tumor location } \\
49.5 \% \text { at } 2 \mathrm{yr}\end{array}$ & No grade $3-5$ toxicity \\
\hline $\begin{array}{l}\text { Haseltine et al. } \\
2015 \text { [87] }\end{array}$ & Central & $\begin{array}{l}\text { 4D-CT with ITV and } \\
\text { CBCT guidance system }\end{array}$ & $36-60$ Gy in $2-5 \mathrm{fx}, 56 \%$ received $45 \mathrm{~Gy}$ in $5 \mathrm{fx}$ & $77.4 \%$ at $2 \mathrm{yr}$ & $63.9 \%$ at $2 \mathrm{yr}$ & $\begin{array}{l}12 \% \text {, four patients } \\
\text { with grade } 5\end{array}$ \\
\hline $\begin{array}{l}\text { Lischalk et al. } \\
2016 \text { [78] }\end{array}$ & Central & $\begin{array}{l}\text { Synchrony respiratory } \\
\text { motion tracking system } \\
\text { with fiducial markers }\end{array}$ & 35-40 Gy/5 fx BED 59.5-72 Gy & $\begin{array}{l}57.4 \% \text { at } 2 \mathrm{yr} \\
\text { No differences } \\
\text { regarding the } \\
\text { prescribed } \\
\text { dose }\end{array}$ & $\begin{array}{c}40 \% \text { at } 2 \mathrm{yr} \\
\text { No differences regarding } \\
\text { the prescribed dose }\end{array}$ & $\begin{array}{l}15 \% \text { (one patient } \\
\text { with grade } 4 \text { ) }\end{array}$ \\
\hline $\begin{array}{l}\text { Lindberg et al. } \\
\quad 2017[88]\end{array}$ & $\begin{array}{l}\text { Central } \leq 1 \mathrm{~cm} \text { from } \\
\text { the proximal bronchial } \\
\text { tree }\end{array}$ & - & $56 \mathrm{~Gy} / 8 \mathrm{fx}$ & - & - & $28 \%$ grade $3-5$ \\
\hline
\end{tabular}

ITV: Internal target volume; Dmean: Mean dose; BED: Biologically equivalent dose; Gy: Gray; fx: Fractions; and yr: Years. 


\section{Treatment Volumes}

The gross tumor volume (GTV) represents the solid tumor and ground glass density in each axial CT slice using a lung window (this value can be based on FDG-PET if available) $[4,24,68]$. An expansion from the GTV to the clinical target volume (CTV) margin is not routinely added for lung SBRT practice. Thus, the CTV margin is commonly $0 \mathrm{~mm}[63,64]$. Grills et al. conducted a Phase II study, called Trial in Stereotactic Lung Radiotherapy, and used a $4 \mathrm{~mm}$ expansion (3-5 $\mathrm{mm}$ ) of the GTV-ITV to create the CTV [65].

The creation of an internal target volume (ITV) is mandatory in this scenario $[4,66,68]$.

The ITV can be created from an eight-phase 4D tomography acquired in a normal respiratory cycle. The GTV is outlined in a free-breathing scan, and it is expanded in four inspiratory and four expiratory phases. When the breath-hold technique is used, ITV creation is not mandatory, as it is significantly reduced compared to the free-breathing phase $[4,24,66,68]$. Finally, the planning target volume (PTV) is created by an isotropic growth of $5 \mathrm{~mm}$ from the ITV (range 3-7 $\mathrm{mm}$ ) [4,24,66,68].

\section{Treatment Dose}

A dose and fractionation with BED of at least 100 Gy should be used [68]. According to the consensus of the ESTRO ACROP, the selection of a scheme depends upon the location and size of the tumor [68]. (see Table 3).

Table 3. SBRT doses and fractionations for lung lesions according to the ESTRO ACROP consensus on the implementation and practice of SBRT for peripheral lesions in early-stage non-small-cell lung cancer.

\begin{tabular}{ccc}
\hline Tumor Location & Dose to PTV & BED10 of the Prescribed Dose to the PTV \\
\hline Peripheral & $3 \times 15$ Gy $(45$ Gy $)$ & 113 Gy BED10 \\
Central & $4 \times 12$ Gy (48 Gy) & 106 Gy BED10 \\
\hline
\end{tabular}

According to CARO, the following doses and fractionations can be used for primary and metastatic lung lesions [44]. (see Table 4).

Table 4. CARO clinical practice guidelines for lung SBRT.

\begin{tabular}{cc}
\hline Prescribed Dose for PTV & BED10 of the Prescribed Dose to the PTV \\
\hline $8 \times 7.5$ Gy $(60 \mathrm{~Gy})$ & 105 Gy BED10 \\
$5 \times 10$ Gy $(50 \mathrm{~Gy})$ & 100 Gy BED10 \\
$4 \times 12$ Gy $(48$ Gy $)$ & 106 Gy BED10 \\
$3 \times 18-20$ Gy $(54-60$ Gy) & $151-180$ Gy BED10 \\
$1 \times 34$ Gy (34 Gy) & 150 Gy BED10 \\
\hline
\end{tabular}

\section{Technical Requirements}

The main technical requirements for SBRT include:

1. Modern linear accelerators to enable image-guided radiation therapy (IGRT) and motion-management systems;

2. Sophisticated immobilization devices [44,89];

3. Quality controls [72].

\subsection{Simulation}

Two critical issues in the simulation of pulmonary SBRT are the immobilization and evaluation of tumor movement [64]. Patients are normally positioned supine with their arms overhead, in a custom immobilization device [90], such as a vacuum-sealed foam bag, a stereotactic frame with a wing board and an alpha-cradle, and an immobilizer for the feet and knees [91]. 
The images required for simulation and planning may include detailed 4D-CT motion estimation, as well as additional soft tissue (MRI) or metabolic (PET) information [92,93]. The latter is particularly useful for tumors that are not well-defined or close to the chest wall [44].

The standard imaging modality for targeting lung tumors and organs at risk (OAR) contouring is tomography, with a maximum thickness per slice of $<3 \mathrm{~mm}$, which must completely include both lungs $[45,94]$ and at least one individual evaluation of the movement of the lungs using 4D-CT. Where this technology is lacking, the tumor movement can be determined by fluoroscopy or scanning in inspiration and expiration [45].

\subsection{Pretreatment Setup and Treatment Delivery}

\subsubsection{IGRT and Motion Management Systems}

The available image-guided radiation therapy (IGRT) and motion management techniques are classified into three domains: Kilovoltage $(\mathrm{kV})$ images, megavoltage (MV) images, and optical images [91].

Conventional $\mathrm{kV}$-imagers can be fluoroscopic imaging devices, retractable $\mathrm{kV}$ sources, detector panels, mounted X-ray imagers, and floor detectors that provide flat radiographic images of the patient. The 3D-CT with cone-beam (3D-CBCT) shows the internal anatomy of the patient before each fraction, allowing the visualization of a range of geometric deviations, such as uncertainties due to movement [91,94]. However, for lung images, the respiratory-phase projections are averaged to reconstruct a single 3D scan, leaving blurred regions of interest or multiple diaphragmatic artifacts that give incorrect information on the tumor amplitude and its position relative to the OARs during breathing. The use of $4 \mathrm{D}-\mathrm{CT}$, by contrast, allows respiratory movement to be considered [91,95].

The $4 \mathrm{D}-\mathrm{CBCT}$ provides complementary information on the interfraction trajectory of the tumor that 3D-CBCT cannot, ensuring that the margins around the target are kept small, reducing their inter-observer variability for patient positionin [15]. MV images can be obtained using electronic portal imaging devices, fan beam MV-CT with tomotherapy, MV-CBCT, and providing 3D images before treatment as a quick and accessible tool to replace dosimetry and verification of modulated deliveries [91].

Repositioning the treatment couch is another important pretreatment intervention. The patient can be positioned and aligned according to markings, tattoos or immobilization devices. After imaging, matching the patient's current position against established landmarks is mandatory, and this can be achieved using either a couch with three translations and one rotation on the anteroposterior axis or one with 6 degrees of freedom, if available. The latter option allows for two extra rotations in the posteroanterior and lateral axes, representing clear advantages to correct positioning errors but is not mandatory for SBRT according to the available guidelines $[91,96,97]$.

Typical strategies for managing respiratory movement include deep inspiration breathhold during treatment, through active control of breathing, abdominal compression, and other mechanical means. Alternatively, radiation can be delivered at specific phases of the respiratory cycle using a respiratory-gated system [91,98]. Another device for the continuous administration of positive air pressure is being tested for its potential use in pulmonary radiotherapy $[91,99]$.

These techniques are adopted to support the treatment in real time, either by moving the full linear accelerator, tilting the gantry, repositioning the patient with a robotic couch or changing the position and shape of the treatment beam with a multi-leaf collimator [95]. The most advanced motion-management technique, which is not based on images, is that of electromagnetic transponders [91,99]. Tumor tracking can also be performed using direct imaging monitoring (fluoroscopy, slow CT or 4D-CT), which is frequently associated with fiducial markers $[64,100]$ or by the evaluation of the chest wall [101]. 


\subsubsection{Sophisticated Immobilization Devices}

A wide variety of immobilization devices exist, from stereotactic body frames to alpha cradles, vacuum bags, foot, and knee supports, and abdominal compressors [44]. The choice of which to use depends upon the experience with each and availability at a given institution.

\subsubsection{Quality Control}

To carry out adequate quality control, the following is required: Small-field dosimetry for commissioning with corresponding detectors (e.g., microchamber) [102]; system-specific end-to-end tests for both static and moving target volumes, especially if a respiratory management system is being used [103]; periodic verification of geometric and dosimetric accuracy according to system-specific guidelines; and daily quality control of the consistency of the stereotactic frame and/or the isocenter image guide system with the isocenter treatment beam. The dosimetric precision must be a maximum of $3 \%$ from a target volume of more than or equal to $2 \mathrm{cc}$ with homogeneous phantoms. For target volumes smaller than $2 \mathrm{cc}$, the measurement uncertainties may be greater than the desired dosimetric precision [72].

The lung dose constraints suggested by the American Association of Physicists in Medicine (AAPM) are V7 $<1500 \mathrm{cc}$ for one fraction, V11.6 < 1500 cc for three fractions (2.9 Gy/fraction), and V12.5 Gy > $1500 \mathrm{cc}$ for five fractions (2.5 Gy/fraction) to an endpoint grade 3 toxicity for basic lung function and V7.4 Gy $<100 \mathrm{cc}$ for one fraction, V12.4 $<1000 \mathrm{cc}$ for three fractions (3.1 Gy/fraction), and V13.5 $<1000 \mathrm{cc}$ for five fractions for pneumonitis [43]. The Japan Clinical Oncology Group (JCOG) 0403 Protocol considered dose constraints for the lung with a mean dose $\leq 18 \mathrm{~Gy}, 40$ Gy irradiated volume $\leq 100 \mathrm{cc}$, V15Gy $<25 \%$, and V20 < 20\% [104]. Dunlap et al. [105] determined a dose constraint for the chest wall of $30 \mathrm{~Gy}$ in three to five fractions to $<30 \mathrm{~cm}^{3}$ to decrease the risk of toxicity without compromising tumor coverage.

Figure 3 summarizes and describes the minimum technical requirements to carry out a SBRT protocol.

In a series of 206 patients treated with SBRT and a median follow-up of 26 months, 54\% of the patients died, the median OS was 33 months, and the median PFS was 13 months. Although the median PFS survival was low at 2, 3, and 5 years $(36 \%, 25 \%$, and $16 \%$, respectively), the local control was high $(85 \%, 83 \%$, and $81 \%$, respectively) [106].

In another series of 219 patients with a median follow-up of 16.5 months, the median OS was 27.6 months, freedom from distant progression (DP) at 2, 3, and 5 years $(46 \%, 40 \%$, and $34 \%$, respectively) were also lower than LC at 2,3 , and 5 years $(84 \%, 78 \%$, and $75 \%$, respectively) [107]. In terms of histology, Takeda et al. [6] reported worse local control in patients with colorectal pulmonary metastases treated with SBRT compared to other tumors. Therefore, dose escalation should be considered in such cases. A retrospective study conducted by Jingu et al. [108] reported a better local control rate with higher BED ( $\geq 100$ Gy BED in patients prescribed with D95 or $\geq 130$ Gy BED in patients prescribed with an isocenter dose) as well in patients with rectal cancer, age $\geq 70$ years old, and receiving adjuvant chemotherapy after SBRT in multivariate analysis. 


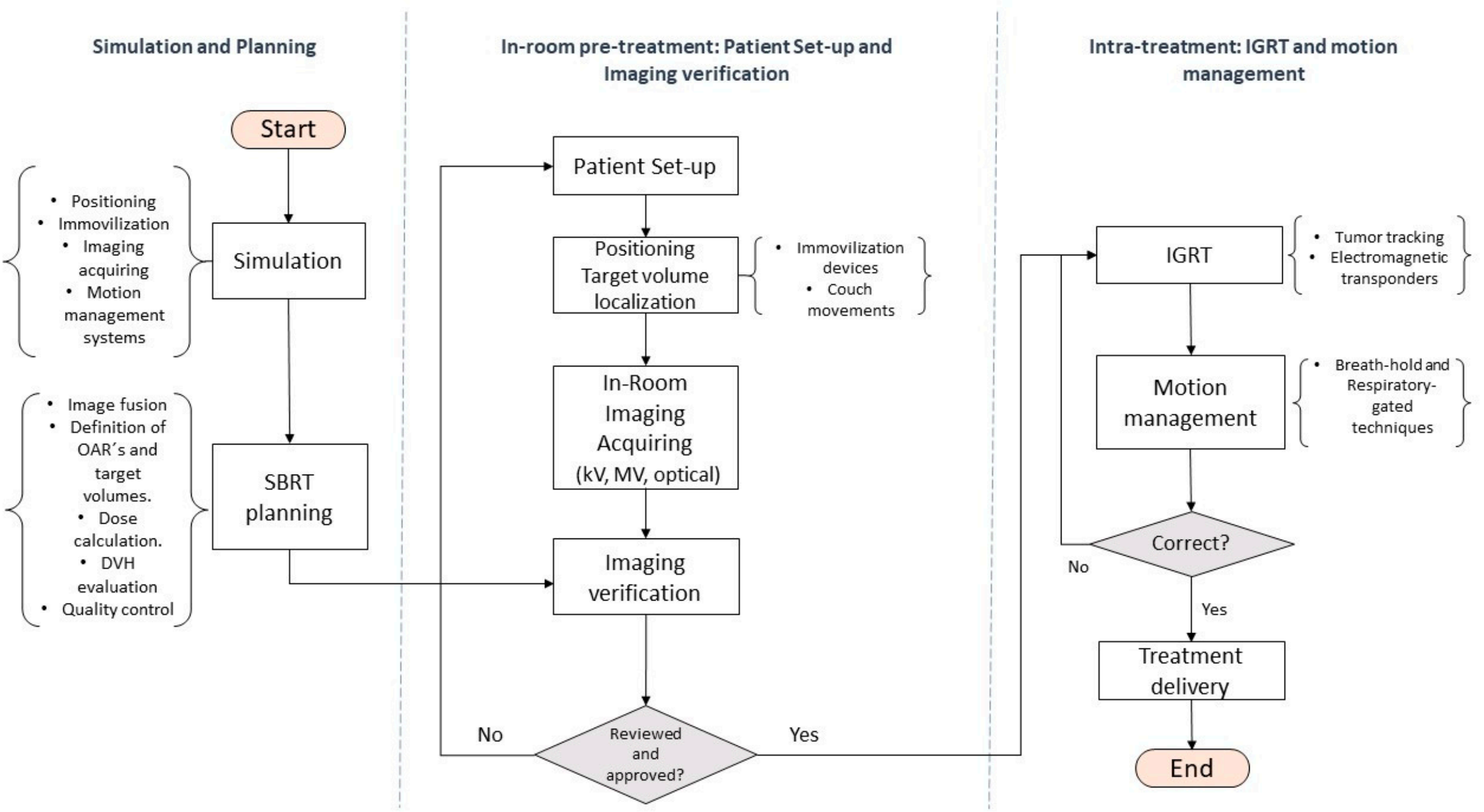

Figure 3. Flow chart describing the minimum technical requirements necessary to carry out the SBRT process. Local control and overall survival. 
A retrospective study including 577 eligible patients utilizing a patient registry analyzed OS in 447 patients and LC in 304 patients. The median OS was 26 months, with actuarial survival at 1,3 , and 5 years of $74.1 \%, 33.3 \%$, and $21.8 \%$, respectively. The median LC was 53 months and had rates of $80.4 \%, 58.9 \%$, and $46.3 \%$, respectively at the same intervals. Contrary to what was described by Sharma, colorectal primary had worse OS than the head and neck or breast primaries, but no differences were seen in LC [70]. Gomez et al. compared local consolidative therapy (LCT) using either radiation therapy or surgery versus observation in patients with NSCLC who did not progress after front-line systemic therapy. This study was closed early, with only 49 patients assigned after a significantly improved progression-free survival (PFS) was seen in the LCT arm. The PFS benefit was a median of 14.2 months in the intervention arm against 4.4 months in the observation $\operatorname{arm}(p=0.022)$. OS had a median benefit of 24.2 months in the intervention arm compared with the observation arm (41.2 vs. 17 months) [29]. The SABR-COMET trial randomized 99 patients (with a life expectancy of at least 6 months) to receive palliative standard of care or standard of care and SABR. The SABR group had a preponderance of prostate cancer patients $(21 \%)$, while the control group had a preponderance of colorectal cancer patients $(27 \%)$. The median OS in the no-SABR group was 28 versus 41 months in the SABR group. However, there was a $20 \%$ increase in grade 2 or worse adverse events, and three patients out of 66 in the SABR treatment group had treatment-related deaths [9]. Although these two major clinical trials were not designed to evaluate the outcome of SBRT for lung metastases, many of the patients included in these two studies were treated with SBRT for lung metastases.

\section{Acute and Late Toxicity}

SBRT for pulmonary metastases, is usually devoid of significant toxicities, with less than $5 \%$ of patients featuring acute grade 2 or higher toxicity: In regards to late toxicity, the most-reported symptom in that study was grade 2 cough $(7.5 \%)$ and grade 2 fatigue $(6 \%)$ [106]. In a study of 207 patients, Kessel reported a higher incidence of grade 2 toxicity and a $9.7 \%$ rate of symptomatic pneumonitis [107].

Toxicities higher than grade 2 are low, with only $2.9 \%$ presenting symptoms within the first 6 months and 2.5\% after 1 year. In Kessel's study, patients who reported late severe dyspnea after the SBRT treatment had been diagnosed with chronic obstructive pulmonary disease before the treatment [107].

\section{Prognostic Factors}

In a series of 206 patients treated with SBRT and a median follow-up of 26 months, $54 \%$ of the patients died, the median OS was 33 months, and the median PFS was 13 months. Although the median PFS survival was low at 2, 3, and 5 years $(36 \%, 25 \%$, and $16 \%$, respectively), the local control was high $(85 \%, 83 \%$, and $81 \%$, respectively) [106].

In another series of 219 patients with a median follow-up of 16.5 months, the median OS was 27.6 months, and rates of distant progression (DP)-free survival at 2, 3, and 5 years ( $46 \%, 40 \%$, and $34 \%$, respectively) were also lower than LC at 2,3 , and 5 years $(84 \%, 78 \%$, and $75 \%$, respectively) [107].

A retrospective study that included 577 eligible patients utilizing a patient registry analyzed OS in 447 patients and LC in 304 patients. The median OS was 26 months, with actuarial survival rates at 1,3 , and 5 years of $74.1 \%, 33.3 \%$, and $21.8 \%$, respectively. The median LC was 53 months with rates of $80.4 \%, 58.9 \%$, and $46.3 \%$, respectively at the same intervals. Contrary to what was described by Sharma [106], colorectal primary had worse OS than head and neck or breast primaries, but no differences were seen in LC [70]. Gomez et al. compared local consolidative therapy (LCT) using either radiation therapy or surgery versus observation in patients with oligometastatic NSCLC who did not progress after front-line systemic therapy. This study was closed early, with only 49 patients assigned after significantly improved progression-free survival (PFS) was seen in the LCT arm. The PFS benefit was a median of 14.2 months in the intervention arm against 4.4 months in the 
observation $\operatorname{arm}(p=0.022)$. OS had a median benefit of 24.2 months in the intervention arm compared with the observation arm (41.2 vs. 17 months) [29]. The SABR-COMET trial randomized 99 patients with oligometastatic cancer at various locations (with a life expectancy of at least 6 months) to receive palliative standard of care or standard of care and SABR. The SABR group had a preponderance of prostate cancer patients (21\%), while the control group had a preponderance of colorectal cancer patients $(27 \%)$. The median OS in the no-SABR group was 28 versus 41 months in the SABR group. However, there was a $20 \%$ increase in grade 2 or worse adverse events, and three patients out of 66 in the SABR treatment group suffered treatment-related death [9].

\section{Conclusions}

- $\quad$ Lung SBRT is an external beam radiation therapy method that accurately delivers a high dose of radiotherapy within a limited number of fractions, often using biologically effective doses $\geq 100 \mathrm{~Gy}^{10}$.

- Its use in treating lung oligometastases is becoming increasingly prevalent with evidence supporting both a clinical benefit and limited toxicity.

- There is variation in the dose-fractionation schedules used, and an optimal regimen for central or ultracentral tumours has yet to be defined.

- The main technical requirements for SBRT include modern linear accelerators with image-guided radiation therapy, advanced immobilization devices, motion management strategies, and quality controls.

Author Contributions: Conceptualization, E.G., I.S., O.D., A.V., A.S., J.F.; and R.B.; methodology, E.G., R.B., A.S. and J.R.; software, O.D., J.F., V.R. and B.L.; validation, A.S., J.P. and C.J.V.; formal analysis, E.G. and A.S.; investigation, E.G., M.C., C.J.V., A.S. and L.H.B.; resources, L.H.B., C.O. and J.F.; data curation, O.D. and C.O.; writing-original draft preparation, E.G. and I.S., A.S. writingreview and editing, E.G., I.S., A.V. and A.S.; visualization, V.R., B.L. and J.R.; supervision, E.G., I.S. and A.S.; project administration, M.C. and J.P.; funding acquisition, A.S.; All authors have read and agreed to the published version of the manuscript.

Funding: This research was funded by Elzbieta Rosnowska-Perera and Norbert Perera.

Conflicts of Interest: The authors declare no conflict of interest.

\section{References}

1. Londero, F.; Grossi, W.; Morelli, A.; Parise, O.; Masullo, G.; Tetta, C.; Livi, U.; Maessen, J.G.; Gelsomino, S. Surgery versus stereotactic radiotherapy for treatment of pulmonary metastases. A systematic review of literature. Futur. Sci. OA 2020, 6 . [CrossRef] [PubMed]

2. Sauter, E.R.; Bolton, J.S.; Willis, G.W.; Farr, G.H.; Sardi, A. Improved survival after pulmonary resection of metastatic colorectal carcinoma. J. Surg. Oncol. 1990, 43, 135-138. [CrossRef]

3. Pastorino, U.; Buyse, M.; Friedel, G.; Ginsberg, R.J.; Girard, P.; Goldstraw, P.; Johnston, M.; McCormack, P.; Pass, H.; Putnam, J.B. Long-term results of lung metastasectomy: Prognostic analyses based on 5206 cases. J. Thorac. Cardiovasc. Surg. 1997, 113, 37-49. [CrossRef]

4. Okunieff, P.; Petersen, A.L.; Philip, A.; Milano, M.T.; Katz, A.W.; Boros, L.; Schell, M. Stereotactic Body Radiation Therapy (SBRT) for lung metastases. Acta Oncol. 2006, 45, 808-817. [CrossRef] [PubMed]

5. Rusthoven, K.E.; Kavanagh, B.D.; Burri, S.H.; Chen, C.; Cardenes, H.; Chidel, M.A.; Pugh, T.J.; Kane, M.; Gaspar, L.E.; Schefter, T.E. Multi-Institutional Phase I/II Trial of Stereotactic Body Radiation Therapy for Lung Metastases. J. Clin. Oncol. 2009, 27, 1579-1584. [CrossRef]

6. Takeda, A.; Kunieda, E.; Ohashi, T.; Aoki, Y.; Koike, N.; Takeda, T. Stereotactic body radiotherapy (SBRT) for oligometastatic lung tumors from colorectal cancer and other primary cancers in comparison with primary lung cancer. Radiother. Oncol. 2011, 101, 255-259. [CrossRef]

7. Dohopolski, M.J.; Horne, Z.; Clump, D.; Burton, S.A.; E Heron, D.E. Stereotactic Body Radiation Therapy for Pulmonary Oligometastases Arising from Non-lung Primaries in Patients without Extrapulmonary Disease. Cureus 2018, 10, e2167. [CrossRef] [PubMed]

8. Gomez, D.R.; Blumenschein, G.R., Jr.; Lee, J.J.; Hernandez, M.; Ye, R.; Camidge, D.R.; Doebele, R.C.; Skoulidis, F.; Gaspar, L.E.; Gibbons, D.L. Local consolidative therapy versus maintenance therapy or observation for patients with oligometastatic non-small-cell lung cancer without progression after first-line systemic therapy: A multicentre randomised, controlled, phase 2 study. Lancet Oncol. 2016, 17, 1672-1682. [CrossRef] 
9. Palma, D.A.; Olson, R.; Harrow, S.; Gaede, S.; Louie, A.V.; Haasbeek, C.; Mulroy, L.; Lock, M.; Rodrigues, G.B.; Yaremko, B.P. Stereotactic ablative radiotherapy versus standard of care palliative treatment in patients with oligometastatic cancers (SABR-COMET): A randomised, phase 2, open-label trial. Lancet 2019, 393, 2051-2058. [CrossRef]

10. Greelish, J.P.; Friedberg, J.S. Secondary pulmonary malignancy. Surg. Clin. N. Am. 2000, 80, 633-657. [CrossRef]

11. Budczies, J.; Von Winterfeld, M.; Klauschen, F.; Bockmayr, M.; Lennerz, J.K.; Denkert, C.; Wolf, T.; Warth, A.; Dietel, M.; Anagnostopoulos, I.; et al. The landscape of metastatic progression patterns across major human cancers. Oncotarget 2015, 6, 570-583. [CrossRef]

12. Krishnan, K.; Khanna, C.; Helman, L.J. The Molecular Biology of Pulmonary Metastasis. Thorac. Surg. Clin. 2006, 16, 115-124. [CrossRef]

13. Popper, H.H. Progression and metastasis of lung cancer. Cancer Metastasis Rev. 2016, 35, 75-91. [CrossRef] [PubMed]

14. Stella, G.M.; Kolling, S.; Benvenuti, S.; Bortolotto, C. Lung-seeking metastases. Cancers 2019, 11, 1010. [CrossRef]

15. Hellman, S.; Weichselbaum, R.R. Oligometastases. J. Clin. Oncol 1995, 13, 8-10. [CrossRef]

16. Weichselbaum, R.R.; Hellman, S. Oligometastases revisited. Nat. Rev. Clin. Oncol 2011, 8, 378-382. [CrossRef] [PubMed]

17. Jeong, S.; Heo, J.S.; Park, J.Y.; Choi, D.W.; Choi, S.H. Surgical resection of synchronous and metachronous lung and liver metastases of colorectal cancers. Ann. Surg Treat. Res. 2017, 92, 82-89. [CrossRef] [PubMed]

18. Correa, R.J.M.; Salama, J.K.; Milano, M.T.; Palma, D.A. Stereotactic Body Radiotherapy for Oligometastasis. Cancer J. 2016, 22, 247-256. [CrossRef]

19. Helou, J.; Thibault, I.; Poon, I.; Chiang, A.; Jain, S.; Soliman, H.; Erler, D.; Yeung, L.; Cheung, P. Stereotactic Ablative Radiation Therapy for Pulmonary Metastases: Histology, Dose, and Indication Matter. Int. J. Radiat. Oncol. Biol. Phys. 2017, 98, 419-427. [CrossRef]

20. Lewis, S.L.; Porceddu, S.; Nakamura, N.; Palma, D.A.; Lo, S.S.; Hoskin, P.; Moghanaki, D.; Chmura, S.J.; Salama, J.K. Definitive Stereotactic Body Radiotherapy (SBRT) for Extracranial Oligometastases. Am. J. Clin. Oncol. 2017, 40, 418-422. [CrossRef]

21. Cheung, P. Stereotactic body radiotherapy for oligoprogressive cancer. Br. J. Radiol. 2016, 89, 20160251. [CrossRef]

22. Schanne, D.H.; Heitmann, J.; Guckenberger, M.; Andratschke, N.H.J. Evolution of treatment strategies for oligometastatic NSCLC patients-A systematic review of the literature. Cancer Treat. Rev. 2019, 80, 101892. [CrossRef] [PubMed]

23. A Palma, D.; A Haasbeek, C.J.; Rodrigues, G.B.; Dahele, M.; Lock, M.; Yaremko, B.; Olson, R.; Liu, M.; Panarotto, J.; Griffioen, G.; et al. Stereotactic ablative radiotherapy for comprehensive treatment of oligometastatic tumors (SABR-COMET): Study protocol for a randomized phase II trial. BMC Cancer 2012, 12, 305. [CrossRef]

24. Oh, D.; Ahn, Y.C.; Seo, J.M.; Shin, E.H.; Park, H.C.; Lim, D.H.; Pyo, H. Potentially curative stereotactic body radiation therapy (SBRT) for single or oligometastasis to the lung. Acta Oncol. 2012, 51, 596-602. [CrossRef]

25. Widder, J.; Klinkenberg, T.J.; Ubbels, J.F.; Wiegman, E.M.; Groen, H.J.M.; Langendijk, J.A. Pulmonary oligometastases: Metastasectomy or stereotactic ablative radiotherapy? Radiother. Oncol. 2013, 107, 409-413. [CrossRef]

26. Salama, J.K.; Hasselle, M.D.; Chmura, S.J.; Malik, R.; Mehta, N.; Yenice, K.M.; Villaflor, V.M.; Stadler, W.M.; Hoffman, P.C.; Cohen, E.; et al. Stereotactic body radiotherapy for multisite extracranial oligometastases: Final report of a dose escalation trial in patients with 1 to 5 sites of metastatic disease. Cancer 2012, 118, 2962-2970. [CrossRef]

27. Yamamoto, T.; Niibe, Y.; Matsumoto, Y.; Dekura, Y.; Oh, R.-J.; Yamashita, H.; Kakuhara, H.; Aoki, M.; Jingu, K. Stereotactic body radiotherapy for pulmonary oligometastases from esophageal cancer: Results and prognostic factors. Anticancer Res. 2020, 40, 2065-2072. [CrossRef]

28. Palma, D.A.; Olson, R.; Harrow, S.; Correa, R.J.M.; Schneiders, F.; Haasbeek, C.J.A.; Rodrigues, G.B.; Lock, M.; Yaremko, B.P.; Bauman, G.S.; et al. Stereotactic ablative radiotherapy for the comprehensive treatment of 4-10 oligometastatic tumors (SABR-COMET-10): Study protocol for a randomized phase III trial. BMC Cancer 2019, 19, 816. [CrossRef] [PubMed]

29. Gomez, D.R.; Tang, C.; Zhang, J.; Blumenschein, G.R.J.; Hernandez, M.; Lee, J.J.; Ye, R.; Palma, D.A.; Louie, A.V.; Camidge, D.R.; et al. Local consolidative therapy vs. maintenance therapy or observation for patients with oligometastatic non-small-cell lung cancer: Long-term results of a multi-institutional, phase II, randomized study. J. Clin. Oncol 2019, 195, 1113-1115. [CrossRef]

30. Miller, W.T.; Aronchick, J.M.; Epstein, D.M.; Gefter, W.B. The troublesome nipple shadow. Am. J. Roentgenol. 1985, 145, 521-523. [CrossRef]

31. Cahan, W.G.; Shah, J.P.; Castro, E.B. Benign solitary lung lesions in patients with cancer. Ann. Surg 1978, 187, 241-244. [CrossRef]

32. Cruickshank, A.; Stieler, G.; Ameer, F. Evaluation of the solitary pulmonary nodule. Intern. Med. J. 2019, 49, 306-315. [CrossRef]

33. Deppen, S.A.; Blume, J.D.; Kensinger, C.D.; Morgan, A.M.; Aldrich, M.C.; Massion, P.P.; Walker, R.C.; McPheeters, M.L.; Putnam, J.B., Jr.; Grogan, E.L. Accuracy of FDG-PET to diagnose lung cancer in areas with infectious lung disease: A meta-analysis. JAMA 2014, 312, 1227-1236. [CrossRef]

34. Mazzola, R.; Fiorentino, A.; Di Paola, G.; Levra, N.G.; Ricchetti, F.; Fersino, S.; Tebano, U.; Pasetto, S.; Ruggieri, R.; Salgarello, M.; et al. Stereotactic Ablative Radiation Therapy for Lung Oligometastases: Predictive Parameters of Early Response by 18 FDG-PET/CT. J. Thorac. Oncol. 2017, 12, 547-555. [CrossRef]

35. Shiono, S.; Endo, M.; Suzuki, K.; Yarimizu, K.; Hayasaka, K. The prognostic value of positron emission tomography/computed tomography in pulmonary metastasectomy. J. Thorac. Dis. 2018, 10, 1738-1746. [CrossRef]

36. Schultz, E.M.; Sanders, G.D.; Trotter, P.R.; Patz, J.E.F.; A Silvestri, G.; Owens, D.K.; Gould, M.K. Validation of two models to estimate the probability of malignancy in patients with solitary pulmonary nodules. Thorax 2008, 63, 335-341. [CrossRef] 
37. Evangelista, L.; Panunzio, A.; Polverosi, R.; Pomerri, F.; Rubello, D. Indeterminate lung nodules in cancer patients: Pretest probability of malignancy and the role of18F-FDG PET/CT. Am. J. Roentgenol. 2014, 202, 507-514. [CrossRef]

38. Hellwig, D.; Baum, R.P.; Kirsch, C.M. FDG-PET, PET/CT and conventional nuclear medicine procedures in the evaluation of lung cancer: A systematic review. NuklearMedizin 2009, 48, 59-69.

39. Truong, M.T.; Viswanathan, C.; Carter, B.W.; Mawlawi, O.; Marom, E.M. PET/CT in the Thorax: Pitfalls. Radiol. Clin. N. Am. 2014 52, 17-25. [CrossRef]

40. Lebofsky, R.; Decraene, C.; Bernard, V.; Kamal, M.; Blin, A.; Leroy, Q.; Frio, T.R.; Pierron, G.; Callens, C.; Bieche, I.; et al. Circulating tumor DNA as a non-invasive substitute to metastasis biopsy for tumor genotyping and personalized medicine in a prospective trial across all tumor types. Mol. Oncol. 2015, 9, 783-790. [CrossRef]

41. Timmerman, R.D.; Paulus, R.; Pass, H.I.; Gore, E.M.; Edelman, M.J.; Galvin, J.; Straube, W.L.; Nedzi, L.A.; McGarry, R.C.; Robinson, C.G.; et al. Stereotactic body radiation therapy for operable early-stage lung cancer findings from the NRG oncology RTOG 0618 trial. JAMA Oncol. 2018, 4, 1263-1266. [CrossRef]

42. Videtic, G.M.; Donington, J.; Giuliani, M.; Heinzerling, J.; Karas, T.Z.; Kelsey, C.R.; Lally, B.E.; Latzka, K.; Lo, S.S.; Moghanaki, D.; et al. Stereotactic body radiation therapy for early-stage non-small cell lung cancer: Executive Summary of an ASTRO Evidence-Based Guideline. Pr. Radiat. Oncol. 2017, 7, 295-301. [CrossRef] [PubMed]

43. Benedict, S.H.; Yenice, K.M.; Followill, D.; Galvin, J.M.; Hinson, W.; Kavanagh, B.; Keall, P.; Lovelock, M.; Meeks, S.; Papiez, L.; et al. Stereotactic body radiation therapy: The report of AAPM Task Group 101. Med. Phys. 2010, 37, 4078-4101. [CrossRef] [PubMed]

44. Sahgal, A.; Roberge, D.; Schellenberg, D.; Purdie, T.; Swaminath, A.; Pantarotto, J.; Filion, E.; Gabos, Z.; Butler, J.; Letourneau, D.; et al. The Canadian Association of Radiation Oncology Scope of Practice Guidelines for Lung, Liver and Spine Stereotactic Body Radiotherapy. Clin. Oncol. 2012, 24, 629-639. [CrossRef]

45. Kirkbride, P.; Cooper, T. Stereotactic Body Radiotherapy. Guidelines for Commissioners, Providers and Clinicians: A National Report. Clin. Oncol. 2011, 23, 163-164. [CrossRef]

46. Guckenberger, M.; Andratschke, N.H.; Alheit, H.; Holy, R.; Moustakis, C.; Nestle, U.; A Sauer, O. Definition of stereotactic body radiotherapy: Principles and practice for the treatment of stage I non-small cell lung cancer. Strahlenther. Onkol. 2014, 190, 26-33. [CrossRef]

47. Brown, J.M.; Carlson, D.J.; Brenner, D.J. The Tumor Radiobiology of SRS and SBRT: Are More than the 5 Rs Involved? Int. J. Radiat. Oncol. 2014, 88, 254-262. [CrossRef]

48. Kim, M.-S.; Kim, W.; Park, I.H.; Kim, H.J.; Lee, E.; Jung, J.-H.; Cho, L.C.; Song, C.W. Radiobiological mechanisms of stereotactic body radiation therapy and stereotactic radiation surgery. Radiat. Oncol. J. 2015, 33, 265-275. [CrossRef]

49. Tanksley, J.; Salama, J.K.; Kirkpatrick, J.P. Rationale for Fractionated SRS and Single SRS Session Approaches. In Stereotactic Radiosurgery and Stereotactic Body Radiation Therapy; Trifiletti, D., Chao, S., Sahgal, A., Sheehan, J., Eds.; Springer: Berlin/Heidelberg, Germany, 2019; pp. 31-40.

50. Roy, S.; Salerno, K.E.; Citrin, D.E. Biology of Radiation-Induced Lung Injury. Semin. Radiat. Oncol. 2021, 31, 155-161. [CrossRef]

51. Lindblom, E.K.; Hui, S.; Brooks, J.; Dasu, A.; Kujawski, M.; Toma-Dasu, I. Radiation-induced Vascular Damage and the Impact on the Treatment Outcome of Stereotactic Body Radiotherapy. Anticancer. Res. 2019, 39, 2721-2727. [CrossRef]

52. Karam, S.D.; Bhatia, S. The radiobiological targets of SBRT: Tumor cells or endothelial cells? Ann. Transl. Med. 2015, 3, 1-4 [CrossRef]

53. Park, H.J.; Griffin, R.J.; Hui, S.; Levitt, S.H.; Song, C.W. Radiation-induced vascular damage in tumors: Implications of vascular damage in ablative hypofractionated radiotherapy (SBRT and SRS). Radiat. Res. 2012, 177, 311-327. [CrossRef]

54. Song, C.W.; Park, H.; Griffin, R.J.; Levitt, S.H. Radiobiology of Stereotactic Radiosurgery and Stereotactic Body Radiation Therapy. In Technical Basis of Radiation Therapy. Medical Radiology; Levitt, S., Purdy, J., Perez, C., Poortmans, P., Eds.; Springer: Berlin/Heidelberg, Germany, 2011; pp. 51-61.

55. Yang, J.; Fowler, J.F.; Lamond, J.P.; Lanciano, R.; Feng, J.; Brady, L.W. Red Shell: Defining a High-Risk Zone of Normal Tissue Damage in Stereotactic Body Radiation Therapy. Int. J. Radiat. Oncol. 2010, 77, 903-909. [CrossRef]

56. Lindblom, E.K.; Antonovic, L.; Dasu, A.; Lax, I.; Wersäll, P.; Toma-Dasu, I. Treatment fractionation for stereotactic radiotherapy of lung tumours: A modelling study of the influence of chronic and acute hypoxia on tumour control probability. Radiat. Oncol. 2014, 9, 149. [CrossRef]

57. Toma-Dasu, I.; Sandström, H.; Barsoum, P.; Dasu, A. To fractionate or not to fractionate? That is the question for the radiosurgery of hypoxic tumors. J. Neurosurg. 2014, 121 (Suppl. 2), 110-115. [CrossRef]

58. Kirkpatrick, J.P.; Meyer, J.J.; Marks, L.B. The linear-quadratic model is inappropriate to model high dose per fraction effects in radiosurgery. Semin. Radiat. Oncol. 2008, 18, 240-243. [CrossRef] [PubMed]

59. Kocher, M.; Treuer, H.; Voges, J.; Hoevels, M.; Sturm, V.; Müller, R.-P. Computer simulation of cytotoxic and vascular effects of radiosurgery in solid and necrotic brain metastases. Radiother. Oncol. 2000, 54, 149-156. [CrossRef]

60. Garcia-Barros, M.; Paris, F.; Cordon-Cardo, C.; Lyden, D.; Rafii, S.; Haimovitz-Friedman, A.; Fuks, Z.; Kolesnick, R. Tumor Response to Radiotherapy Regulated by Endothelial Cell Apoptosis. Science 2003, 300, 1155-1159. [CrossRef]

61. Fuks, Z.; Kolesnick, R. Engaging the vascular component of the tumor response. Cancer Cell 2005, 8, 89-91. [CrossRef] [PubMed] 
62. Moding, E.J.; Castle, K.D.; Perez, B.A.; Oh, P.; Min, H.D.; Norris, H.; Ma, Y.; Cardona, D.; Lee, C.-L.; Kirsch, D.G. Tumor cells, but not endothelial cells, mediate eradication of primary sarcomas by stereotactic body radiation therapy. Sci. Transl. Med. 2015, 7, 278ra34. [CrossRef]

63. Giuliani, M.E.; Bissonnette, J.-P.; Lo, S.; Teh, B.S.; A Mayr, N.; Machtay, M. Target contouring \& treatment planning in lung SBRT. Clin. Insights Stereotact Body Radiat. Ther. Lung Cancer 2013, 145-159. [CrossRef]

64. Dahele, M.; Pearson, S.; Purdie, T.; Bissonnette, J.-P.; Franks, K.; Brade, A.; Cho, J.; Sun, A.; Hope, A.; Marshall, A.; et al. Practical Considerations Arising from the Implementation of Lung Stereotactic Body Radiation Therapy (SBRT) at a Comprehensive Cancer Center. J. Thorac. Oncol. 2008, 3, 1332-1341. [CrossRef]

65. Grills, I.S.; Hugo, G.; Kestin, L.L.; Galerani, A.P.; Chao, K.K.; Wloch, J.; Yan, D. Image-Guided Radiotherapy via Daily Online Cone-Beam CT Substantially Reduces Margin Requirements for Stereotactic Lung Radiotherapy. Int. J. Radiat. Oncol. 2008, 70, 1045-1056. [CrossRef]

66. Timmerman, R.; Paulus, R.; Galvin, J.; Michalski, J.; Straube, W.; Bradley, J.; Fakiris, A.; Bezjak, A.; Videtic, G.; Johnstone, D. Stereotactic body radiation therapy for inoperable early stage lung cancer. JAMA 2010, 303, 1070-1076. [CrossRef]

67. Wegner, R.E.; Abel, S.; Hasan, S.; Schumacher, L.Y.; Colonias, A. Stereotactic Body Radiotherapy (SBRT) for Oligometastatic Lung Nodules: A Single Institution Series. Front. Oncol. 2019, 9, 334. [CrossRef]

68. Guckenberger, M.; Andratschke, N.; Dieckmann, K.; Hoogeman, M.S.; Hoyer, M.; Hurkmans, C.; Tanadini-Lang, S.; Lartigau, E.; Romero, A.M.; Senan, S.; et al. ESTRO ACROP consensus guideline on implementation and practice of stereotactic body radiotherapy for peripherally located early stage non-small cell lung cancer. Radiother. Oncol. 2017, 124, 11-17. [CrossRef] [PubMed]

69. Kilmer, P.D. Review Article: Review Article. J. Theory Pract. Crit. 2010, 11, 369-373. [CrossRef]

70. Ricco, A.; Davis, J.; Rate, W.; Yang, J.; Perry, D.; Pablo, J.; D’Ambrosio, D.; Sharma, S.; Sundararaman, S.; Kolker, J.; et al. Lung metastases treated with stereotactic body radiotherapy: The RSSearch ${ }^{\circledR}$ patient Registry's experience. Radiat. Oncol. 2017, 12, 1-8. [CrossRef] [PubMed]

71. Bernard, M.E.; Critchfield, L.; Kudrimoti, M. Safety of Stereotactic Body Radiation Therapy for Seven Ipsilateral Lung lesions. Cureus 2020, 12, e8759. [CrossRef]

72. Guckenberger, M.; Baus, W.W.; Blanck, O.; Combs, S.E.; Debus, J.; Engenhart-Cabillic, R.; Gauer, T.; Grosu, A.L.; Schmitt, D.; Tanadini-Lang, S.; et al. Definition and quality requirements for stereotactic radiotherapy: Consensus statement from the DEGRO/DGMP Working Group Stereotactic Radiotherapy and Radiosurgery. Strahlenther. Onkol. 2020, 196, 417-420. [CrossRef] [PubMed]

73. Pennathur, A. Lung SBRT. In Stereotactic Radiosurgery and Stereotactic Body Radiation Therapy (SBRT); Dwight, E., Ed.; Springer Publishing Company: Berlin/Heidelberg, Germany, 2019; pp. 183-200.

74. Chang, J.H.; Poon, I.; Erler, D.; Zhang, L.; Cheung, P. The safety and effectiveness of stereotactic body radiotherapy for central versus ultracentral lung tumors. Radiother. Oncol. 2018, 129, 277-283. [CrossRef] [PubMed]

75. Timmerman, R.; McGarry, R.; Yiannoutsos, C.; Papiez, L.; Tudor, K.; DeLuca, J.; Ewing, M.; Abdulrahman, R.; Desrosiers, C.; Williams, M.; et al. Excessive Toxicity When Treating Central Tumors in a Phase II Study of Stereotactic Body Radiation Therapy for Medically Inoperable Early-Stage Lung Cancer. J. Clin. Oncol. 2006, 24, 4833-4839. [CrossRef] [PubMed]

76. Davis, J.N.; Medbery, C.; Sharma, S.; Pablo, J.; Kimsey, F.; Perry, D.; Muacevic, A.; Mahadevan, A. Stereotactic body radiotherapy for centrally located early-stage non-small cell lung cancer or lung metastases from the RSSearch ${ }^{\circledR}$ patient registry. Radiat Oncol. 2015, 10, 113. [CrossRef]

77. Bral, S.; Gevaert, T.; Linthout, N.; Versmessen, H.; Collen, C.; Engels, B.; Verdries, D.; Everaert, H.; Christian, N.; De Ridder, M.; et al. Prospective, Risk-Adapted Strategy of Stereotactic Body Radiotherapy for Early-Stage Non-Small-Cell Lung Cancer: Results of a Phase II Trial. Int. J. Radiat. Oncol. 2011, 80, 1343-1349. [CrossRef]

78. Lischalk, J.W.; Malik, R.M.; Collins, S.P.; Collins, B.T.; Matus, I.A.; Anderson, E.D. Stereotactic body radiotherapy (SBRT) for high-risk central pulmonary metastases. Radiat. Oncol. 2016, 11, 1-10. [CrossRef]

79. Milano, M.T.; Chen, Y.; Katz, A.W.; Philip, A.; Schell, M.C.; Okunieff, P. Central thoracic lesions treated with hypofractionated stereotactic body radiotherapy. Radiother. Oncol. 2009, 91, 301-306. [CrossRef]

80. Chaudhuri, A.A.; Tang, C.; Binkley, M.S.; Jin, M.; Wynne, J.F.; von Eyben, R.; Hara, W.Y.; Trakul, N.; Loo, B.W.; Diehn, M. Stereotactic ablative radiotherapy (SABR) for treatment of central and ultra-central lung tumors. Lung Cancer 2015, 89, 50-56. [CrossRef]

81. Bezjak, A.; Paulus, R.; Gaspar, L.E.; Timmerman, R.D.; Straube, W.L.; Ryan, W.F.; Garces, Y.I.; Pu, A.T.; Singh, A.K.; Videtic, G.M.; et al. Safety and Efficacy of a Five-Fraction Stereotactic Body Radiotherapy Schedule for Centrally Located Non-Small-Cell Lung Cancer: NRG Oncology/RTOG 0813 Trial. J. Clin. Oncol. 2019, 37, 1316-1325. [CrossRef]

82. Al-Hallaq, H.A.; Chmura, S.; Salama, J.K.; Winter, K.A.; Robinson, C.G.; Pisansky, T.M.; Borges, V.; Lowenstein, J.R.; McNulty, S.; Galvin, J.M.; et al. Rationale of technical requirements for NRG-BR001: The first NCI-sponsored trial of SBRT for the treatment of multiple metastases. Pr. Radiat. Oncol. 2016, 6, e291-e298. [CrossRef] [PubMed]

83. Unger, K.; Ju, A.; Oermann, E.; Suy, S.; Yu, X.; Vahdat, S.; Subramaniam, D.; Harter, K.W.; Collins, S.P.; Dritschilo, A.; et al. CyberKnife for hilar lung tumors: Report of clinical response and toxicity. J. Hematol. Oncol. 2010, 3, 39. [CrossRef] [PubMed]

84. Rowe, B.P.; Boffa, D.J.; Wilson, L.D.; Kim, A.W.; Detterbeck, F.C.; Decker, R.H. Stereotactic Body Radiotherapy for Central Lung Tumors. J. Thorac. Oncol. 2012, 7, 1394-1399. [CrossRef] 
85. Nuyttens, J.J.; Zyp, N.C.V.D.V.V.; Praag, J.; Aluwini, S.; van Klaveren, R.J.; Verhoef, C.; Pattynama, P.M.; Hoogeman, M.S. Outcome of four-dimensional stereotactic radiotherapy for centrally located lung tumors. Radiother. Oncol. 2012, 102, 383-387. [CrossRef]

86. Nuyttens, J.J.; Zyp, N.C.V.D.V.V.; Verhoef, C.; Maat, A.; Van Klaveren, R.J.; Van Der Holt, B.; Aerts, J.; Hoogeman, M. Stereotactic Body Radiation Therapy for Oligometastases to the Lung: A Phase 2 Study. Int. J. Radiat. Oncol. 2015, 91, 337-343. [CrossRef] [PubMed]

87. Haseltine, J.M.; Rimner, A.; Gelblum, D.; Modh, A.; Rosenzweig, K.E.; Jackson, A.; Yorke, E.D.; Wu, A.J. Fatal complications after stereotactic body radiation therapy for central lung tumors abutting the proximal bronchial tree. Pr. Radiat. Oncol. 2016, 6, e27-e33. [CrossRef] [PubMed]

88. Lindberg, K.; Bergström, P.; Brustugun, O.T.; Engelholm, S.; Grozman, V.; Hoyer, M.; Karlsson, K.; Khalil, A.; Kristiansen, C.; Lax, I.; et al. OA24.05 The Nordic HILUS-Trial-First Report of a Phase II Trial of SBRT of Centrally Located Lung Tumors. J. Thorac. Oncol. 2017, 12, S340. [CrossRef]

89. Román, A.; Perez-Rozos, A.; Otero, A.; Jodar, C.; García-Ríos, I.; Lupiañez-Perez, Y.; Medina, J.A.; Gomez-Millan, J. Efficacy and safety of a simplified SBRT regimen for central and peripheral lung tumours. Clin. Transl. Oncol. 2019, 22, 144-150. [CrossRef] [PubMed]

90. Boyer, M.J.; Ricardi, U.; Ball, D.; Salama, J.K. Ablative Approaches for Pulmonary Metastases. Thorac. Surg. Clin. 2016, 26, 19-34. [CrossRef] [PubMed]

91. Caillet, V.; Booth, J.T.; Keall, P. IGRT and motion management during lung SBRT delivery. Phys. Medica 2017, 44, 113-122. [CrossRef]

92. Solberg, T.D.; Balter, J.M.; Benedict, S.H.; Fraass, B.A.; Kavanagh, B.D.; Miyamoto, C.T.; Pawlicki, T.; Potters, L.; Yamada, Y. Quality and safety considerations in stereotactic radiosurgery and stereotactic body radiation therapy: Executive summary. Pr. Radiat. Oncol. 2012, 2, 2-9. [CrossRef]

93. Ricardi, U.; Badellino, S.; Filippi, A.R. What do radiation oncologists require for future advancements in lung SBRT? Phys. Medica 2017, 44, 150-156. [CrossRef]

94. Purdie, T.; Bissonnette, J.-P.; Franks, K.; Bezjak, A.; Payne, D.; Sie, F.; Sharpe, M.B.; Jaffray, D. Cone-Beam Computed Tomography for On-Line Image Guidance of Lung Stereotactic Radiotherapy: Localization, Verification, and Intrafraction Tumor Position. Int. J. Radiat. Oncol. 2007, 68, 243-252. [CrossRef] [PubMed]

95. Shah, C.; Grills, I.S.; Kestin, L.L.; McGrath, S.; Ye, H.; Martin, S.K.; Yan, D. Intrafraction Variation of Mean Tumor Position during Image-Guided Hypofractionated Stereotactic Body Radiotherapy for Lung Cancer. Int. J. Radiat. Oncol. Biol. Phys. 2012, 82, 1636-1641. [CrossRef]

96. Xia, D.; Paysan, P.; Zhang, Z.; Seghers, D.; Brehm, M.; Munro, P. Optimization-Based Reconstruction from Megavoltage Cone-beam CT Data in Image Guided Radiation Therapy. Available online: https://www.researchgate.net/publication/312068 407_Optimization-based_Reconstruction_from_Megavoltage_Cone-beam_CT_Data_in_Image_Guided_Radiation_Therapy / citation/download (accessed on 18 January 2021).

97. Shah, A.P.; Langen, K.M.; Ruchala, K.J.; Cox, A.; Kupelian, P.A.; Meeks, S.L. Patient Dose from Megavoltage Computed Tomography Imaging. Int. J. Radiat. Oncol. 2008, 70, 1579-1587. [CrossRef]

98. Salama, J.K.; Kirkpatrick, J.; Yin, F.-F. Stereotactic body radiotherapy treatment of extracranial metastases. Nat. Rev. Clin. Oncol. 2012, 9, 654-665. [CrossRef]

99. Shah, A.P.; Kupelian, P.A.; Waghorn, B.J.; Willoughby, T.R.; Rineer, J.M.; Mañon, R.R.; Vollenweider, M.A.; Meeks, S.L. Real-Time Tumor Tracking in the Lung Using an Electromagnetic Tracking System. Int. J. Radiat. Oncol. 2013, 86, 477-483. [CrossRef] [PubMed]

100. Goldstein, J.D.; Lawrence, Y.R.; Appel, S.; Landau, E.; Ben-David, M.A.; Rabin, T.; Benayun, M.; Dubinski, S.; Weizman, N.; Alezra, D.; et al. Continuous positive airway pressure for motion management in stereotactic body radiation therapy to the ILung: A Controlled Pilot study. Int. J. Radiat. Oncol. Biol. Phys. 2015, 93, 391-399, Earlier versions of this work were accepted for presentation at the third ESTRO Forum, 24-28 April 2015, in Barcelona, Spain, and ISCORT, 27-30 January 2015, in Eilat, Israel Study. [CrossRef]

101. Molitoris, J.K.; Diwanji, T.; Snider, J.W.; Mossahebi, S.; Samanta, S.; Onyeuku, N.; Mohindra, P.; Choi, J.I.; Simone, C.B. Optimizing immobilization, margins, and imaging for lung stereotactic body radiation therapy. Transl. Lung Cancer Res. 2018, 8, 24-31. [CrossRef] [PubMed]

102. Dasa, I.J.; Cheng, C.-W.; Watts, R.J.; Ahnesjoö, A.; Gibbons, J.; Li, X.A.; Lowenstein, J.; Mitra, R.K.; Simon, W.E.; Zhu, T.C. TG-106 of the Therapy Physics Committee of the AAPM. Accelerator beam data commissioning equipment and procedures: Report of the TG-106 of the Therapy Physics Committee of the AAPM. Med. Phys. 2008, 35, 4186-4215. [CrossRef]

103. American College of Radiology. ACR-ASTRO Practice Parameter for Radiation Oncology. [Updated 2018 ; Cited 2021 March 10]. Available online: https:/ / www.acr.org/-/media/ACR/Files/Practice-Parameters/radonc.pdf?la=en (accessed on 18 January 2021).

104. Matsuo, Y. Interinstitutional variations in planning for stereotactic body radiation therapy for lung cancer. Int. J. Radiat. Oncol. Biol. Phys. 2007, 68, 416-425. [CrossRef]

105. Dunlap, N.; Biedermann, G.; Yang, W.; Cai, J.; Benedict, S.; Sheng, K.; Kavanagh, B.; Larner, J. Chest Wall Volume Receiving More than 30 Gy Predicts Risk of Severe Pain and/or Rib Fracture Following Lung SBRT. Int. J. Radiat. Oncol. 2008, 72, S36. [CrossRef] 
106. Sharma, A.; Duijm, M.; Hoop, E.O.-D.; Aerts, J.G.; Verhoef, C.; Hoogeman, M.; Nuyttens, J.J. Survival and prognostic factors of pulmonary oligometastases treated with stereotactic body radiotherapy. Acta Oncol. 2018, 58, 74-80. [CrossRef]

107. Kessel, K.A.; Grosser, R.C.E.; Kraus, K.M.; Hoffmann, H.; Oechsner, M.; Combs, S.E. Stereotactic body radiotherapy (SBRT) in patients with lung metastases-Prognostic factors and long-term survival using patient self-reported outcome (PRO). BMC Cancer 2020, 20, 442. [CrossRef] [PubMed]

108. Jingu, K.; Matsuo, Y.; Onishi, H.; Yamamoto, T.; Aoki, M.; Murakami, Y.; Yamashita, H.; Kakuhara, H.; Nemoto, K.; Sakayauchi, T.; et al. Dose Escalation Improves Outcome in Stereotactic Body Radiotherapy for Pulmonary Oligometastases from Colorectal Cancer. Anticancer. Res. 2017, 37, 2709-2713. [CrossRef] [PubMed] 